\title{
Structural Stress Analysis of an Engine Cylinder Head
}

\author{
R. Tichánek, M. Španiel, M. Diviš
}

This paper deals with a structural stress analysis of the cylinder head assembly of the C/28 series engine. A detailed FE model was created for this purpose. The FE model consists of the main parts of the cylinder head assembly, and it includes a description of the thermal and mechanical loads and the contact interaction between their parts. The model considers the temperature dependency of the heat transfer coefficient on wall temperature in cooling passages. The paper presents a comparison of computed and measured temperature. The analysis was carried out using the FE program ABAQUS.

Keywords: structural stress analysis, FEM, internal-combustion engine.

\section{Notation}

$\begin{array}{ll}q & \text { heat flux }\left[\mathrm{W} \cdot \mathrm{m}^{-2}\right] \\ T_{0} & \text { bulk temperature }[\mathrm{K}] \\ T & \text { face temperature }[\mathrm{K}] \\ k & \text { contact heat-transfer coefficient }\left[\mathrm{W} \cdot \mathrm{m}^{-2} \mathrm{~K}^{-1}\right] \\ h & \text { heat-transfer coefficient }\left[\mathrm{W} \cdot \mathrm{m}^{-2} \mathrm{~K}^{-1}\right]\end{array}$

\section{Introduction}

The cylinder head is one of the most complicated parts of an internal combustion engine. It needs to contain a combustion chamber, intake and exhaust valve ports, valves with valve seats and guides, a fuel injector and a complex of cooling passages. In the combustion chamber there are peaks of combustion pressure and temperature of the order of $15 \mathrm{MPa}$ and $2500 \mathrm{~K}$. The heat fluxes and temperature nonuniformities lead to thermal stress, which further escalates the mechanical loading from combustion pressure. The maximum temperature of the head material is much lower, and the regions around the combustion chamber need to be safely cooled to prevent overheating. Placing the cooling passages very close to the most exposed regions is not always possible because of space demands, which results in limited cooling in these regions. The parts of the engine head assembly are usually made of different materials with varying thermal expansion. These facts lead to many compromises in design, which can be sources of failures in operation. Avoiding the risk of failure in operation is one of the targets of engine designers. The design of the engine head must be tested under operational conditions. This procedure is necessary, but expensive. FE modeling of the cylinder head assembly operational conditions is an appropriate complement to operational testing.

A detailed FE strength analysis can provide valuable information about the temperature distribution and mechanical stresses in the overall assembly of the cylinder head. This information is especially useful in regions where experimental data is barely obtainable. Temperature and mechanical stresses are analyzed using temperature field, combustion pressure in the combustion chamber and other mechanical loads, i.e. bolt pre-stress, moulded seats and valve guides, etc. The resulting displacement/stress fields may be utilized for the evaluating the operational conditions, i.e. the contact pressure uniformity between the valves and valve seats as well as strength and failure resistance of the assembly. Such infor- mation contributes to a detailed understanding of the thermal and mechanical processes in the cylinder-head assembly under engine operation, which is a prerequisite for further optimization of engine design.

In this study, we emphasize the problematic regions where proper cooling is limited. The regions around the valve seats experience thermal loading from in-cylinder burning gases during the combustion period and also during the exhaust phase - from burned gases flowing through the exhaust valve and along the exhaust-port walls. Although the temperatures of the exhaust gases are significantly lower than peak in-cylinder temperatures, the rapid movement of flowing gases and the duration of the exhaust period exposes parts around the exhaust valves to heat. The main portion of the heat accumulated in the valve is conducted through the contact surface of the valve seat. Deformations of these parts accompanied by improper contact and the occurrence of leakage on the conical valve contact face dramatically increase the thermal loading of the valves and, may lead to their destruction. The modeling of the operating condition of the combustion engine needs to include a model of cooling with the possibility of local boiling. The simplified model is used to increase the heat transfer coefficient depending on the surface temperature in the cooling passages, which simulates local boiling. This model is implemented in the heat transfer analysis.

\section{Cylinder head assembly}

In this study, the cylinder head of a large turbo-charged direct-injection diesel engine is analyzed. The engine is used in power generators. The basic parameters of the engine are: bore $275 \mathrm{~mm}$, stroke $330 \mathrm{~mm}$, maximum brake mean effective pressure $1.96 \mathrm{MPa}$, nominal speed $750 \mathrm{rpm}$.

The cylinder head (Fig. 1, link 1) is made of cast iron. The cylinder head assembly contains two intake valves (Fig. 1, link 6 ) and two exhaust valves (Fig. 1, link 7), which are made from forged alloy steel. The valve guides $(2,3)$ and also the valve seats $(4,5)$ are pressed into the head. The exhaust-valve seats are cooled by cooling water flowing through the annular cavities around the seats. The fuel injector is situated in the center of the cylinder, and it is held in place with pre-pressed bolt connections. The bottom face of the cylinder head, which is directly exposed to the in-cylinder gases, is cooled by special bores, which represents a complication in the design of this mechanically highly loaded region of the cylinder head. The 


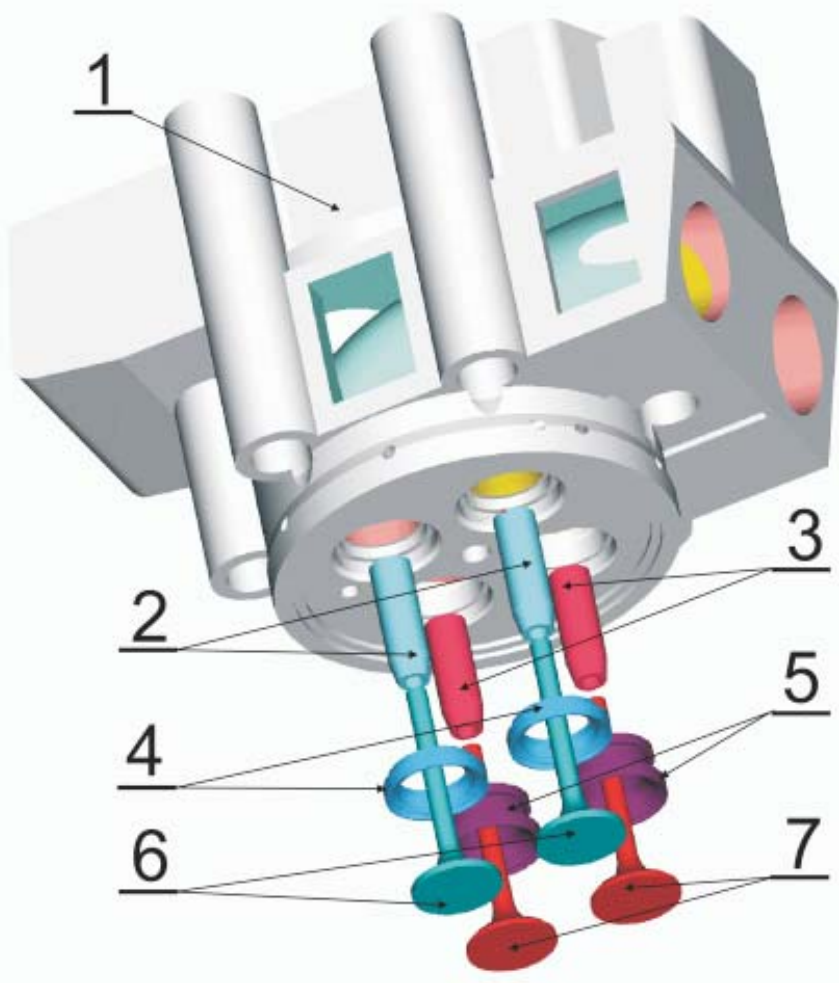

Fig. 1: Cylinder head assembly

cylinder head assembly lies on the cylinder, and it is fixed with six pre-pressed bolt connections.

\section{The FE model}

The FE model includes all components mentioned above. The real design of the cylinder head was slightly modified in details to enable manageable meshing. The model of the cylinder head block was created using PRO/ENGINEER 3D product development software and was imported as a CAD model, unlike the models of other components (valves, seats, valve guides and fuel-injector), which were developed directly in ABAQUS CAE. Some parts of the valves and fuel-injector were considerably simplified or completely left out, as they

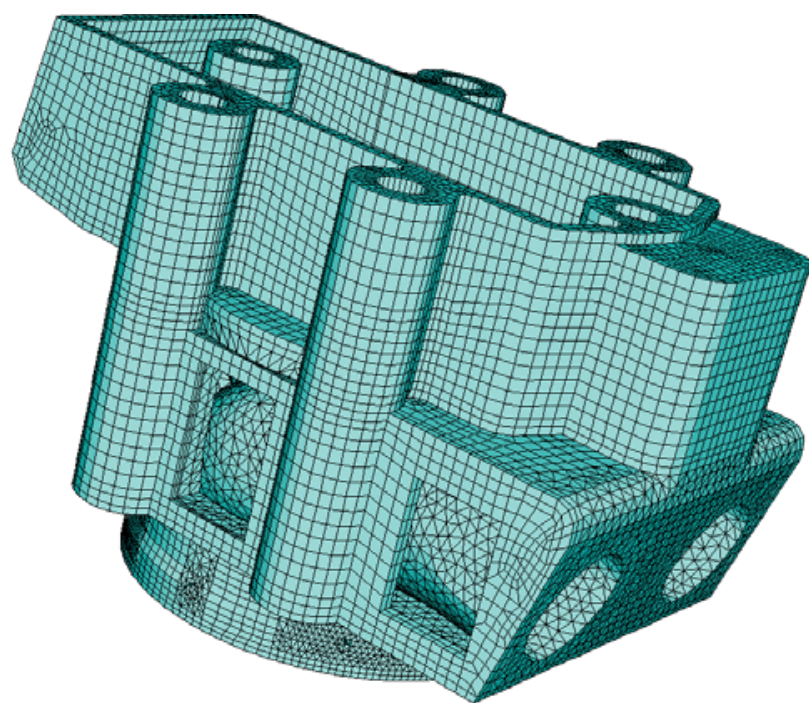

were considered to have a negligible influence on the results. The mesh geometry of the basic parts is shown in. It consists mainly of tetrahedron DC3D4 (158 586) and brick DC3D8 (41 844) elements. The bolts are modeled as beams B31.

\section{Interactions and boundary conditions}

Although the thermal loadings of engine parts vary considerably in time due to the cyclical nature of engine operation, the computations were performed assuming steady-state heat fluxes evaluated on the basis of time-averaged values. Taking into account the speed of the periodic changes and the thermal inertia of the components of the cylinder head,
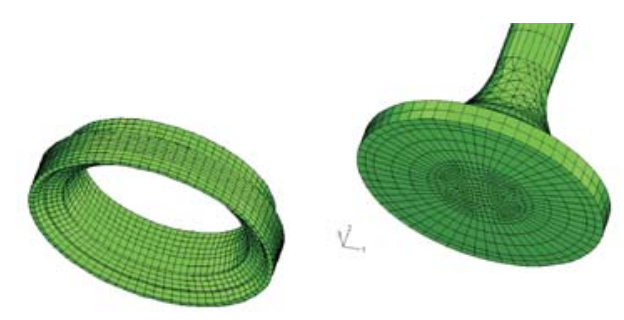

Fig. 2: Mesh geometry 


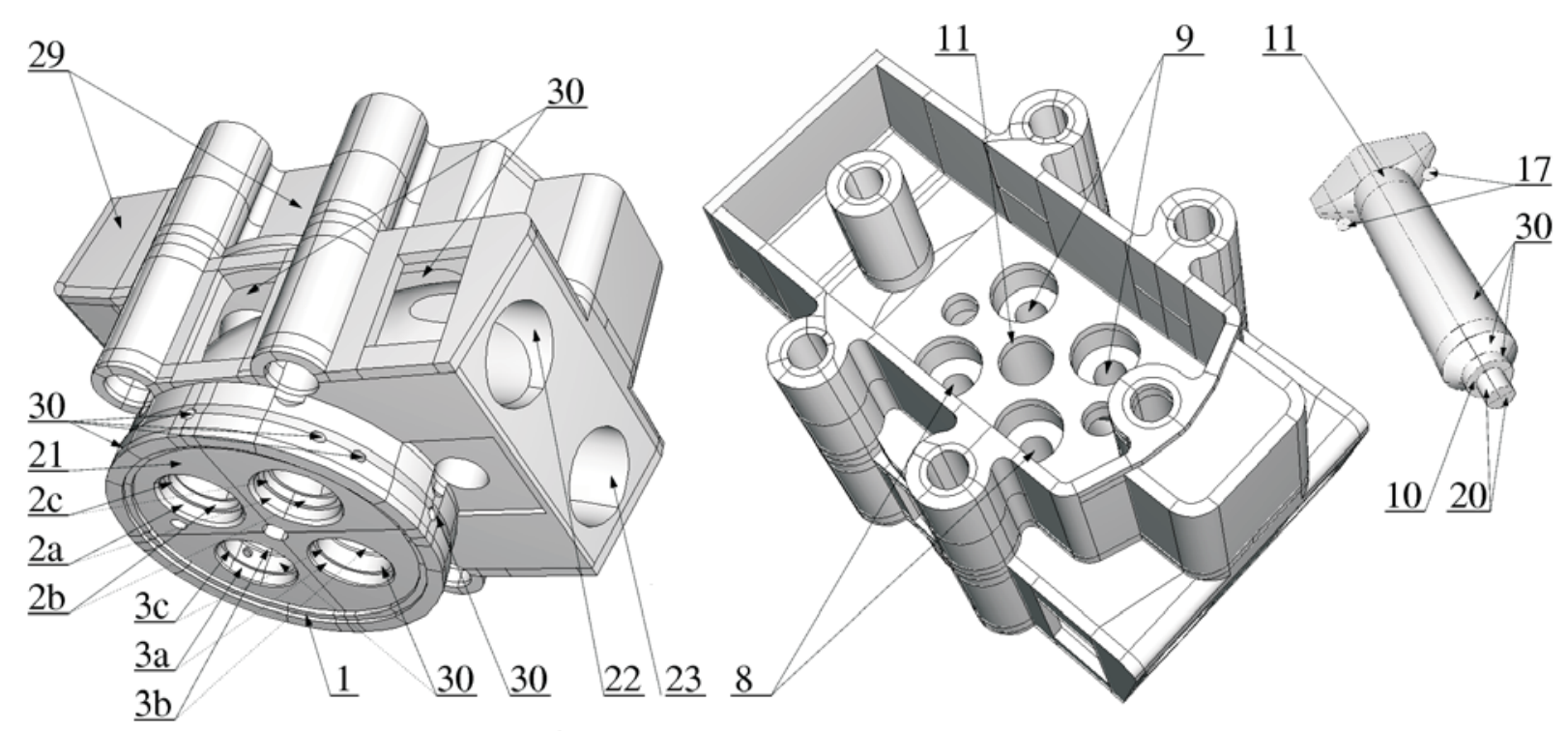

Fig. 3: Interactions and boundary conditions on the cylinder-head block

the temperature variations are damped out within a small distance from the wall surface $(\sim 1 \mathrm{~mm})$, and this simplification is therefore acceptable.

The thermal contact interactions between the individual parts of the cylinder head assembly are described by heat flux $\dot{q}_{\mathrm{AB}}$ from the solid face A to $\mathrm{B}$, which is related to the difference of their surface temperatures $T_{\mathrm{A}}, T_{\mathrm{B}}$ according to

$$
\dot{q}_{\mathrm{AB}}=k\left(T_{\mathrm{B}}-T_{\mathrm{A}}\right),
$$

where $k$ is the contact heat-transfer coefficient. The values of the coefficient used in the present analysis are summarized in Table 1 . They follow the values reported in [3]. The value of $k=6000 \mathrm{Wm}^{-2} \mathrm{~K}^{-1}$ was used for all the metal contacts (Fig. 3, Fig. 4; links 1-4, 6-11), except that of valves vs. their guides (Fig. 3, Fig. 4; links 5, 7), where the value is $k=600 \mathrm{Wm}^{-2} \mathrm{~K}^{-1}$. The boundary conditions of surfaces in contact with flowing gases are described as a steady-flow convective heat-transfer problem, where the heat flux $q$ transferred from a solid surface at temperature $T$ to a fluid at bulk temperature $T_{0}$ is determined from the relation

$$
\dot{q}=h\left(T-T_{0}\right),
$$

where $h$ denotes the heat-transfer coefficient. It depends on the flow properties of the fluid and the geometry of the surfaces.

The functional forms of these relationships are usually developed with the aid of dimensional analysis. In the present study, the values of gas-side heat-transfer coefficients and bulk gas temperatures (i.e. for in-cylinder surfaces and intake and exhaust port walls) were obtained from a detailed thermodynamic analysis of the engine operating cycle performed using the 0-D thermodynamic model OBEH, (see [4]). The analysis uses Eichelberg's well-known empirical heat-transfer coefficient correlation. The remaining boundary conditions on the outside surfaces mostly exposed to the ambient air
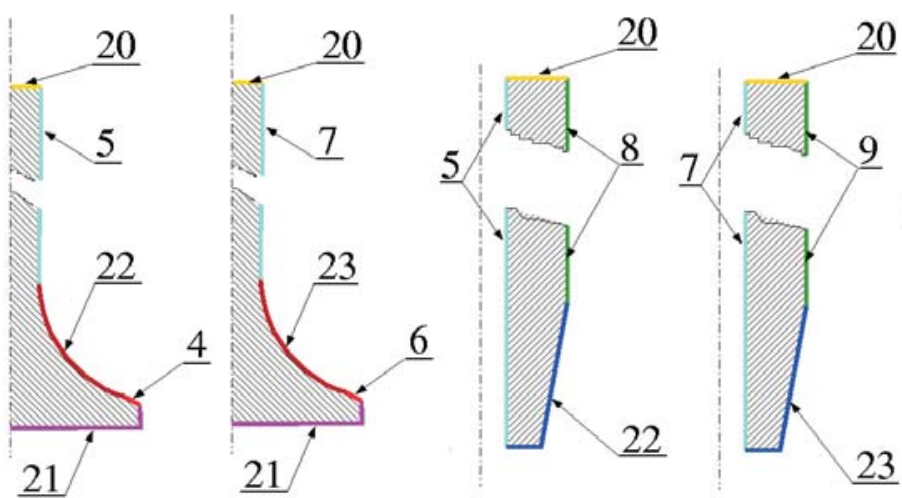

20
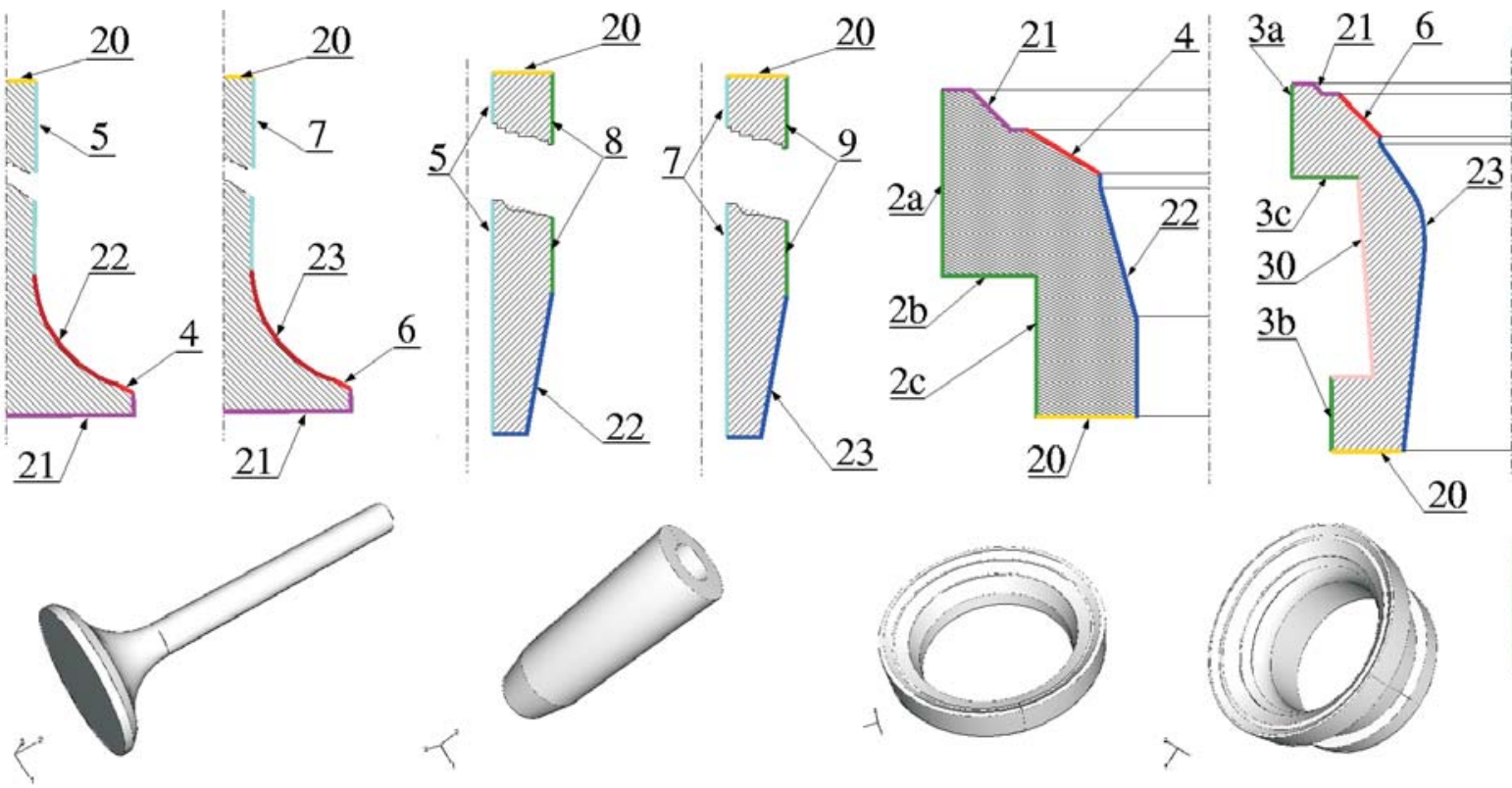

Fig. 4: Interactions and boundary conditions on other parts of the cylinder-head assembly 


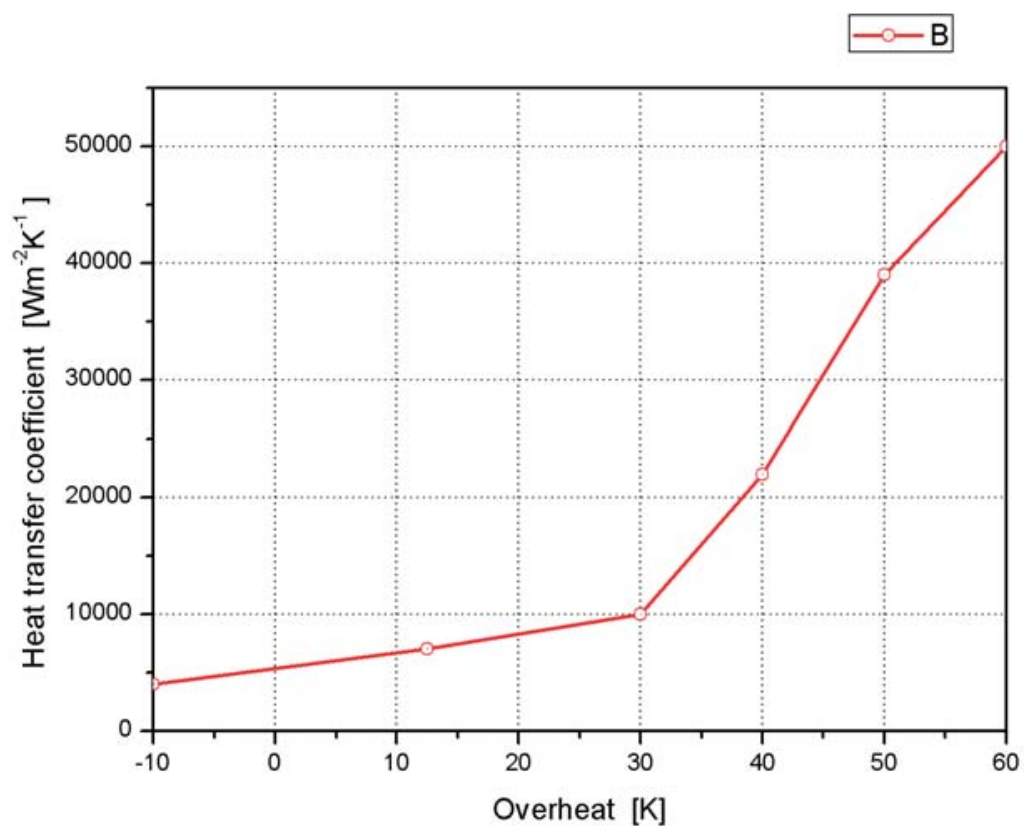

Fig. 5: Dependency of the heat-transfer coefficient of the cooling passages on the surface overheat

temperature are described using estimated values of the heat-transfer coefficient; in special cases the heat-transfer is neglected. More detailed information on the used values is provided in Table lin conjunction with Fig. 3 and Fig. 4 .

The possibility of the cooling water exceeding the boiling point was anticipated, (see [1]). The dependency of the heat-transfer coefficient on surface temperature is shown in Fig. 5. This figure presents experimental data of the heat-transfer coefficient increasing with the use of pure water boiling under flow conditions, (see [2]).

The contact interactions between the head and the valve guides/ports, the valves and the guides/ports, the head and are included in the structural analysis of the head. Five basic states were studied.

Table 1: Description of the boundary condition

\begin{tabular}{|c|c|c|c|}
\hline $\begin{array}{l}\text { Boundary } \\
\text { condition } \\
\text { description }\end{array}$ & Link & $\begin{array}{l}\text { Heat transfer } \\
\text { coefficient } \\
{\left[\mathrm{Wm}^{-2} \mathrm{~K}^{-1}\right]}\end{array}$ & $\begin{array}{l}\text { Bulk } \\
\text { temp. } \\
{[\mathrm{K}]}\end{array}$ \\
\hline $\begin{array}{l}\text { Insulated surfaces } \\
\text { (negligible } \\
\text { heat-transfer rate) }\end{array}$ & 20 & $\begin{array}{c}0 \\
\text { (adiabatic) }\end{array}$ & - \\
\hline $\begin{array}{l}\text { Free surfaces } \\
\text { (contact with } \\
\text { ambient air) }\end{array}$ & 29 & 5 & 320 \\
\hline Cooling passages & 30 & (see Fig. 4.) & 350 \\
\hline In-cylinder surfaces & 21 & 450 & 1120 \\
\hline $\begin{array}{l}\text { Intake-port } \\
\text { surfaces }\end{array}$ & 22 & 800 & 330 \\
\hline $\begin{array}{l}\text { Exhaust-port } \\
\text { surfaces }\end{array}$ & 23 & 800 & 700 \\
\hline
\end{tabular}
the gasket ring, the pre-stressed bolts and the valve springs

1) Assembly: The gasket ring is constrained in the cylinder side. The head is bolted on the cylinder gasket ring with six pre-stressed bolts fully constrained in the cylinder side. The valve seats/guides are pressed into the head using contact constraints. The valves interact with the guides by special MPC constraints, and with the seats by contact constraints. The pre-stressed valve springs are inserted between the valve and the head. The fuel injector is constrained on the head bottom inner surface by contact and pressed onto it by two pre-stressed bolts.

Table 2: Comparison between the computed with measured temperatures

\begin{tabular}{|c|c|c|}
\hline \multirow{2}{*}{$\begin{array}{c}\text { Measured } \\
\text { point }\end{array}$} & \multicolumn{2}{|c|}{ Temperature [K] } \\
\cline { 2 - 3 } & Measured & Computed \\
\hline 1 & 425 & 551.8 \\
\hline 2 & 509 & 533.1 \\
\hline 3 & 442 & 424.1 \\
\hline 4 & 0 & 430 \\
\hline 5 & 412 & 422 \\
\hline 6 & 448 & 432 \\
\hline 7 & 415 & 425 \\
\hline 8 & 468 & 478 \\
\hline 9 & 394 & 427 \\
\hline 10 & 430 & 490.6 \\
\hline 11 & 400 & 432.6 \\
\hline 12 & 361 & 437.9 \\
\hline 13 & 414 & 523.8 \\
\hline
\end{tabular}


2) Average pressure load: The assembly is loaded by average in-cylinder pressure $p=1.96 \mathrm{MPa}$ on the head bottom outer surface and valve bottoms.

3) Maximum pressure load: The head bottom outer surface and valve bottoms are loaded by maximum in-cylinder pressure $p=12 \mathrm{MPa}$.

4) Maximum pressure and temperature load: The assembly is loaded by maximum pressure and the temperature field from the previous steady state heat transfer analysis.

5) Average pressure and temperature load: The assembly is loaded by the average pressure and temperature field from the previous steady state heat transfer analysis.

\section{Results}

The experimentally determined temperatures provided by the engine manufacturer were compared with the computed results. The thermocouples were placed in special bores. All the bores were situated at a distance of $18 \mathrm{~mm}$ from the bottom margin of the cylinder head, Fig. 6. Despite a lack of further detailed information on the conditions of the experiment (errors caused by the measuring equipment, influence of the location and fixation of the thermocouples in the bores, etc.), the authors found the data provided to be a usable and useful resource for verification of the presented model. A comparison of the computed and measured temperatures is presented in Table 2 .

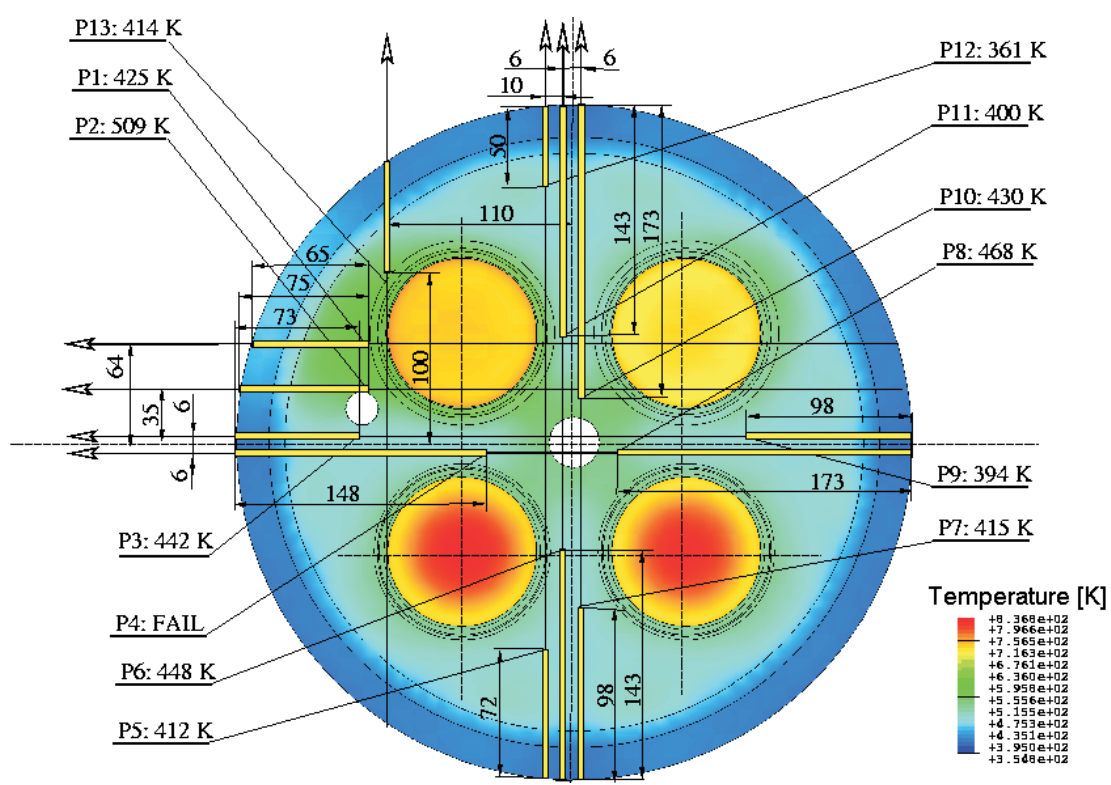

Fig. 6: Distribution of measured points P1-P13 over the head

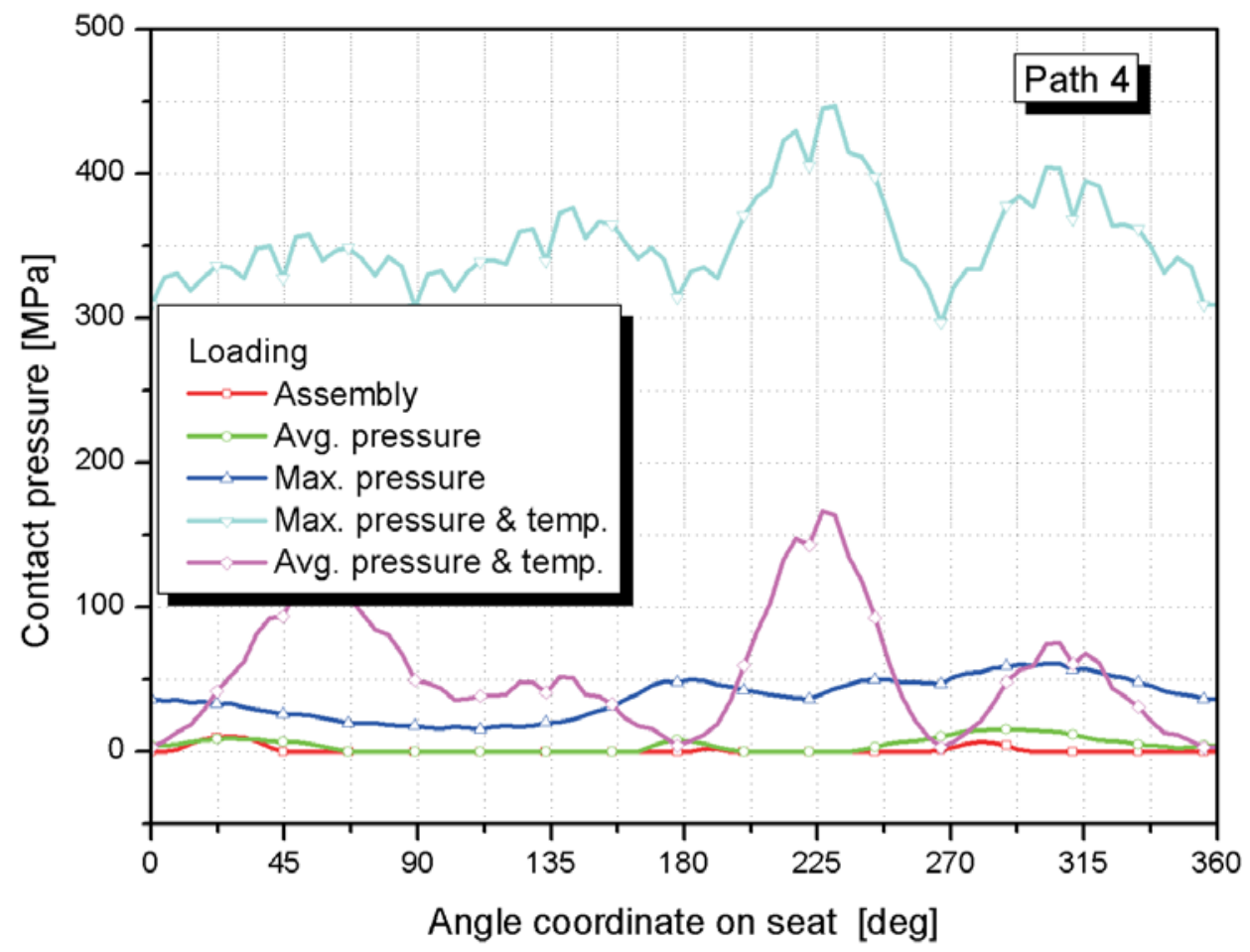

Fig. 7: Contact pressure on the intake valve seat 


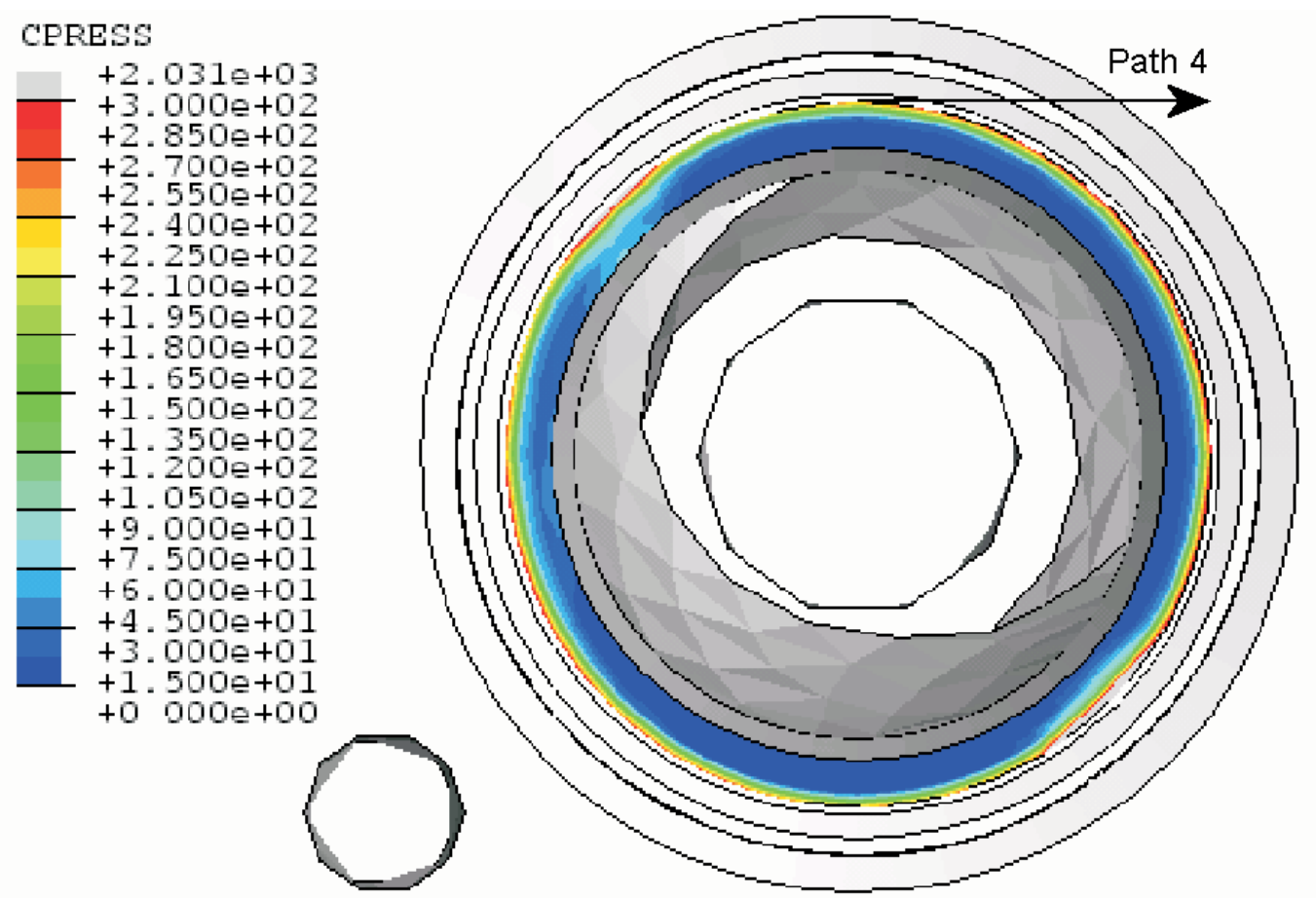

Fig. 8: Contact pressure distribution on the intake valve seat

As an example of the structural analysis, the contact pressure distribution between the intake valve and the seat is shown in . The idealized contact surface is conical. Two edge circles of this surface establish the inner and outer path that the contact pressure is mapped in. The position of both the inner and outer circles is measured as an angle coordinate in the cylindrical system associated to the axis of the valve. The curves document a strong dependency of the valve/seat contact in relation to temperature loading. In a cold state, the inner edge transfers more loads, whereas in the hot state the outer edge is simply overloaded.

\section{Conclusion}

The experimental data provided by the engine manufacturer was compared with the computed results. The thermocouples were placed in special bores at a distance of $18 \mathrm{~mm}$ from the bottom margin of the cylinder head. The heat transfer analysis acknowledged the importance of including the assumption of local boiling in the analysis. The structural analysis results have not been fully evaluated yet. The influence of valve seat deformation due to assembly, pressure and thermal loading on the contact pressure distribution between the valves and seats is significant.

\section{Acknowledgments}

This research was conducted in the Josef Božek Research Center of Engine and Automotive Engineering, supported by the Ministry of Education of the Czech Republic, project No. LN00B073.

\section{References}

[1] Španiel, M., Macek, J., Diviš, M., Tichánek, R.: "Diesel Engine Head Steady State Analysis, MECCA - Journal of Middle European Construction and Design of Cars, Vol. 2 (2003), No. 3, p. 34-41, ISSN 1214-0821.
[2] McAssey, E. V., Kandlikar, S. G.: Convective Heat Transfer of Binary Mixtures under Flow Boiling Conditions. Villanova University, Villanova, PA USA.

[3] Horák, F., Macek, J.: "Use of Predicted Fields in Main Parts of Supercharged Diesel Engine." Proceedings of XIX. Conference of International Centre of Mass and Heat Transfer. New York: Pergamon Press, 1987.

[4] Macek, J., Vávra, J., Tichánek, R., Diviš, M.: Výpočet oběhu motoru $6 c 28$ a stanoveni okrajoryích podminek pro pevnostni a deformační výpočet dna hlavy válce. ČVUT v Praze, Fakulta strojní, VCJB, 2001 (in Czech).

[5] Macek, J., Vítek, O., Vávra, J.: Kogeneračni jednotka s plynovým motorem o výkonu větším než $3 M W-I I$. ČVUT v Praze, Fakulta strojní, 2000 (in Czech).

Ing. Radek Tichánek

phone: +420224352507

tichanek@fsid.cvut.cz

Department of Automotive and Aerospace Engineering

Ing. Miroslav Španiel, CSc.

phone: +420224352561

spaniel@lin.fsid.cvut.cz

Department of Mechanics

Ing. Marcel Diviš

phone: +420224351827

divis@student.fsid.cvut.cz

Department of Automotive and Aerospace Engineering

Josef Božek Research Center

Czech Technical University in Prague

Technická 4

16607 Praha 6, Czech Republic 